\title{
The Impact Of Basel III On Italian Banks' Loan Rates: An Accounting-Based Approach
}

Pasquale di Biase, University of Foggia, Italy

\begin{abstract}
This paper empirically investigates the impact of the new capital requirements imposed under Basel III on bank lending rates. A general accounting equilibrium model is developed in order to map the change in the average interest rate on bank loans which is required to preserve the economic performance and the market value of financial institutions under the new regulatory framework. The study refers to the Italian banking system. According to our estimates, the longterm impact of heightened capital requirements on bank loan rates is likely to be modest. In our baseline scenario, we find evidence that each percentage point increase in the capital ratio can be recovered by increasing interest rates with which borrowers are charged by only 5.75 basis points. We conclude that the Italian banking system should be able to adjust to the higher capital requirements imposed by Basel III through a set of operative and commercial levers with no significant effects on the cost of credit for companies and consumers.
\end{abstract}

Keywords: Basel III; Capital Requirements; Loan Rates; Italian Banks

\section{INTRODUCTION}

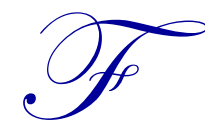

ollowing the outbreak of the global financial crisis, the Basel Committee on Banking Supervision (BCBS) approved, in December 2009, a package of proposals for consultation - the Basel III reform aimed at strengthening banks' capital adequacy and liquidity position in order to avoid new episodes of widespread financial distress (BCBS, 2009). The Basel III reform is organised around three main areas of intervention: higher capital ratios, higher-quality regulatory capital standards, and new liquidity requirements ${ }^{1}$.

Under the new Basel agreement, the minimum requirement for banks' common equity, the capital with the highest loss absorbing capacity, is raised from the 2\% level set under Basel II to $4.5 \%$ of Risk-Weighted Assets $(R W A s)$. The Tier 1 capital requirement, consisting of common equity and other equity instruments that must henceforth comply with stricter criteria, is increased from $4 \%$ to $6 \%$ of $R W A s$. The Basel Committee also introduced a capital conservation buffer and a countercyclical buffer. The first is a 2,5\% (of $R W A s$ ) capital buffer, consisting of common equity, which aims at improving banks' ability to absorb losses during periods of financial distress. The second is a further capital buffer, composed of common equity and other types of capital with high loss-absorbing capacity, varying between $0 \%$ and $2.5 \%$ of RWAs according to national circumstances. The countercyclical buffer will be imposed in periods of high aggregate credit growth to mitigate fluctuations in the flow of credit during economic downturns. For the most part, the new capital standards will be gradually phased in between 2013 and 2019.

This paper aims at exploring the impact of the new capital requirements on bank lending rates. The underlying hypothesis is that an increase in capital ratios, by involving lower leverage levels (as equity replaces debt), can have a negative effect on banks' return on equity (ROE) and, as a consequence, on the market value of

\footnotetext{
${ }^{1}$ Namely a short-term requirement - the Liquidity Coverage Ratio (LCR) - and a long-term requirement - the Net Stable Funding Ratio (NSFR) - (BCBS, 2010a; Préfontaine, Desrochers, \& Godbout, 2010).
} 
banks' common stocks. These effects might, in turn, prompt banks to raise the average interest rate charged to borrowers and/or to reduce the volume of their lending portfolio.

The likely impact of the Basel III reform on bank loan rates is then estimated by calibrating the increment in the average loan rate which is required to offset the fall in bank's ROE resulting from the structural shift in leverage. In doing so, we develop a pragmatic equilibrium model based on simple accounting relations in order to map out how a change in a bank's capital structure affects its return on equity and which increment in credit price is needed to restore bank's return on equity to the current steady-state levels.

Our evidence is based on some key assumptions. First, banks are expected to adjust to the higher capital requirement imposed by Basel III by expanding common equity while also reducing debt funding by an off-setting amount. Second, in our base case scenario banks are assumed to pass on any additional cost resulting from heightened capital standards only by raising lending rates, with no changes in other income and/or cost drivers. Third, we will focus on two steady-states, the current one and the long-term steady state (in which banks are assumed to have completed their transition to heightened capital requirements), without considering the transition period to Basel III. Finally, in this study the overall supply of bank credit is taken as an exogenous factor. In other words, we did not take into any account the competitive pressures inside the lending business or the price elasticity of demand for credit.

The study refers to the Italian banking industry. More specifically, our evidence is based on a representative bank's financial statement drawn up by combining Bankscope data for the Italian bank companies listed on the Milan Stock Exchange over the period 2005-2010².

Our findings suggest that the long-term effect of increased capital requirements on banks' lending activity is likely to be small. We also find substantial evidence that the Italian banking sector will be able to adjust easily to the new regulatory framework by engaging a variety of business levers, with no significant effect on loan interest rates. We believe these results are highly significant in evaluating the long-term impact of the Basel III reform on the Italian economy.

The outline of the paper is as follows: section 2 provides the literature review; in section 3 we introduce the reference sample and the representative Italian bank's balance sheet and income statement; in section 4 the accounting-based model is developed; section 5 provides quantitative estimates regarding the effects of increased capital ratios; finally, section 6 synthesizes the main results and possible future research directions.

\section{LITERATURE REVIEW}

There is a large body of academic literature on bank capital and regulatory requirements. One strand of literature highlights the benefits implied by increased capital ratios. Admati, DeMarzo, Hellwig, and Pfleiderer (2011) observe that financial institutions operating with high levels of leverage are strongly exposed to insolvency risk. The authors conclude that higher capital requirements may reduce the probability of bank bankruptcies and the negative externalities associated with it. A number of studies have drawn similar conclusions (BSBC, 2010b; Berger \& Bouwman, 2011).

Conversely, a second body of research outlines the cost associated with heightened capital standards. Most of those studies explore the long-term effects of higher capital requirements on bank lending policies. Cosimano and Hakura (2011) find that the world's 100 largest banks would elevate lending rates by 12 basis points for each percentage point by which their equity-to-asset ratio is increased. Elliott (2009) and Kashyap, Stein, and Hansen (2010) identify the impact of a decrease in leverage on U.S. banks. Through an accounting-based analysis, Elliott finds that the effects of financial system regulatory reform on loan rates is modest, especially if banks are able to adjust to higher capital requirements through a combination of actions involving a variety of income and cost drivers. The author estimates that, if the common equity rises by $2 \%$ of the loans value (from $6 \%$ to $8 \%$ ), banks

\footnotetext{
${ }^{2}$ We did not include data from the last fiscal year financial statements because economic performance of the Italian banks in 2011 has been particularly negative and we believe their inclusion could have negatively affected our result's reliability.
} 
would need to increase loan rates by 39 basis points to maintain their target return on equity. Kashyap et al. (2010) regressed the equity to assets ratio against a number of bank lending spread proxies, finding no significant relationship between financial leverage and loan spreads, apart from those related to the tax shield on interest expenses. In their baseline scenario, the authors estimate a 2.5 basis point increase in loan rates for each percentage point by which the equity to assets ratio is raised.

The Basel Committee on Banking Supervision (BCBS) and the Financial Stability Board (FSB) published two documents providing estimates of the economic impact of bank capital and liquidity reforms. The Basel Committee finds that, in the long-run, each percentage point increase in TIER 1 capital leads to a 13 basis point increase in lending spreads (BCBS 2010). The Macroeconomic Assessment Group (MAG) of the joint FSB-BCBS provides estimates concerning the effects on both lending rates and volumes associated with increased minimum capital and liquidity requirements: a 1 percentage point increase in the capital ratio turns into a 16 basis points rise in lending spreads and a 1.9\% decline in lending volumes (MAG 2010).

By applying an accounting-based model to aggregated banking financial statements, King (2010) and Slovik and Cournede (2011) reach similar conclusions. King estimates a 15 basis points increment in the lending spreads of a representative bank for each percentage point by which the required capital ratio is increased. Slovik and Cournede, referring to the three main OECD economies, find that each percentage point increase in the capital to risk-weighted assets ratio is likely to lead to an average rise of lending spreads by about 14 basis points. This value is estimated to be greater for the U.S. banking sector (20.5) and lower for the Eurozone (14.3) and the Japanese economy (8.4).

In complementing the studies mentioned above, the present research makes a twofold contribution to existing literature. First, the paper derives its empirical estimates by developing a quantitative model based on general accounting relations, which we believe can reproduce the effects of structural shifts in a bank's leverage in a simple and flexible way. Second, this study analyzes the impact of an increase in minimum capital requirements for the Italian banking industry, as opposed to the Anglo-Saxon context or large reference areas, such as the OECD countries, which existing literature has typically focused on. In fact, the consequences of Basel III could be different for the Italian banking industry, which is characterized by a large number of small commercial banks, focused mainly on traditional forms of intermediation.

\section{DATA DESCRIPTION: THE REPRESENTATIVE BANK'S FINANCIAL STATEMENT}

The empirical estimates presented in this paper refer to a balance sheet and income statement representative of the aggregated Italian banking sector. The accounting values are based on six-years' (2005-2010) Bankscope data for the Italian banks and bank-holding companies that were listed on the Milan Stock Exchange at the end of 2010. Since Bankscope database deletes historical information on banks that no longer exist, we collected all the missing accounting data from the official financial statements released by banks on their websites. The final sample consists of 24 companies and 146 bank-year observations.

Table 1 shows the sample's composition. Total market capitalization amounts to about 89,000 Million Euros, with a size-based distribution characterized by the presence of a large number of small banks and a far lower number of large financial institutions (the two largest banks in the sample represent more than $63 \%$ of the total market capitalization), which results in a very low computational weight for most of the banks.

The stylized Italian bank's financial statement comes from a two-step median calculation. First, we obtained for each company an average balance sheet and income statement by calculating the arithmetic means of its annual accounting values over the period 2005-2010. This way we aimed at normalizing accounting data and isolating any possible error in data reporting. In a second step, we averaged the median accounting values resulting from the first step by weighting each bank's data by the market capitalization of the same bank as at the end of 2010 . 
Table 1: Composition of the sample

\begin{tabular}{clcc}
\hline N. & \multicolumn{1}{c}{ Bank name } & $\begin{array}{c}\text { Market capitalization } \\
\text { (Millions of Euros) }\end{array}$ & Weight \\
\hline 1 & UniCredit & 30,308 & $34.1 \%$ \\
2 & Intesa Sanpaolo & 25,869 & $29.1 \%$ \\
3 & Mediobanca & 5,758 & $6.5 \%$ \\
4 & Monte dei Paschi di Siena & 4,729 & $5.3 \%$ \\
5 & UBI Banca & 4,213 & $4.7 \%$ \\
6 & Banca Carige & 3,050 & $3.4 \%$ \\
7 & Banca popolare dell'Emilia Romagna & 2,384 & $2.7 \%$ \\
8 & Banco Popolare & 2,187 & $2.5 \%$ \\
9 & Banca Popolare di Sondrio & 1,911 & $2.1 \%$ \\
10 & CREDEM - Credito Emiliano & 1,533 & $1.7 \%$ \\
11 & Credito Bergamasco & 1,263 & $1.4 \%$ \\
12 & Banca Popolare di Milano & 1,095 & $1.2 \%$ \\
13 & Banca Generali & 1,008 & $1.1 \%$ \\
14 & Credito Valtellinese & 778 & $0.9 \%$ \\
15 & Banca Intermobiliare di Investimenti e Gestioni & 653 & $0.7 \%$ \\
16 & Banco di Desio e della Brianza & 516 & $0.6 \%$ \\
17 & Credito Artigiano & 364 & $0.4 \%$ \\
18 & Banca Profilo & 296 & $0.3 \%$ \\
19 & Banca Ifis & 284 & $0.3 \%$ \\
20 & Banca popolare dell'Etruria e del Lazio & 229 & $0.3 \%$ \\
21 & Banca Finnat & 182 & $0.2 \%$ \\
22 & IW Bank & 147 & $0.2 \%$ \\
23 & Banca Popolare di Spoleto & 101 & $0.1 \%$ \\
24 & Banco di Sardegna & 62 & $0.1 \%$ \\
\hline Total & & $\mathbf{8 8 , 9 1 9}$ & $\mathbf{1 0 0 \%}$ \\
\hline
\end{tabular}

Table 2 presents the aggregated balance sheet and the income statement of our representative bank. Items are shown both in Millions of Euros and as a percentage of total assets. Loans are about $60 \%$ of total investments, followed by trading assets $(25.4 \%)$. Assets are funded primarily by deposits (37.2\%) and wholesale funding \& trading liabilities $(36.1 \%)$. Shareholders' equity represents $7.5 \%$ of the bank's total assets. Looking at the income statement, we find that net interest income is $1.6 \%$ of total assets, while non-interest income is $0.98 \%$. That is to say, non-interest income is about $61 \%$ of interest income (i.e. $0.98 \% / 1.6 \%$ ), which demonstrates Italian banks' direction towards traditional forms of intermediation. Total operating expenses are $2 \%$ of total assets, with personnel expenses representing about half of the total operating expenses (since $0.94 \% / 2 \%=47 \%$ ). The return on assets (net income / total assets) is $0.53 \%$, while the return on equity (net income / total equity) is around $7 \%$.

Regarding capital ratios, the risk-weighted assets (RWAs) are close to half of the total assets (46.8\%), while the TIER 1 Capital Ratio amounts to $7.7 \%$ and the Total Capital Ratio to $11.6 \%$. Therefore, both ratios are about 3.5 percentage points above their minimum level. This is not surprising, considering that financial institutions aim to hold more capital than the minimum required. Indeed, as observed by Berger, Herring, and Szego (1995) and Maccario, Sironi, and Zazzara (2002), the effective capital standard is made up of the minimum amount explicitly required by Regulators plus an implicit capital requirement. Such an implicit requirement consists of an additional capital buffer that financial institutions hold, either as a consequence of the silent pressure exerted by national supervisory authorities, or as a means of avoiding the costs resulting from a possible fall of capital ratios below the regulatory minimum levels. Hence, as banks strive to maintain their current level of capital buffer, they will likely react to any increase in explicit capital requirements by proportionally raising new equity capital. 
Table 2: The representative Bank's balance sheet and income statement

\begin{tabular}{|c|c|c|c|c|c|}
\hline Balance Sheet & Euros (Millions) & $\begin{array}{c}\% \text { of } \\
\text { Total } \\
\text { Assets }\end{array}$ & Income Statement & $\begin{array}{c}\text { Euros } \\
\text { (Millions) }\end{array}$ & $\begin{array}{c}\% \text { of } \\
\text { Total } \\
\text { Assets }\end{array}$ \\
\hline Cash and Cash Equivalent & 6,511 & 1.26 & 1. Interest Income & 18,908 & 3.66 \\
\hline Loans to Banks & 43,108 & 8.34 & 2. Interest Expenses & 10,604 & 2.05 \\
\hline Net Loans & 300,138 & 58.10 & A. Net Interest Income (1 - 2) & 8,304 & 1.61 \\
\hline Total Securities & 131,153 & 25.39 & 3. Trading Income & 378 & 0.07 \\
\hline Fixed Assets & 5,391 & 1.04 & 4. Fees and Commissions & 4,617 & 0.89 \\
\hline Intangible Assets & 15,213 & 2.94 & $\begin{array}{l}\text { 5. Other Non-Interest } \\
\text { Income - Expenses }\end{array}$ & 79 & 0.02 \\
\hline Other Assets & 15,100 & 2.92 & $\begin{array}{l}\text { B. Total Non-Interest Income } \\
(3+4+5)\end{array}$ & 5,074 & 0.98 \\
\hline Total Assets & 516,614 & 100 & C. Total Revenues $(\mathrm{A}+\mathrm{B})$ & 13,378 & 2.59 \\
\hline Interbank Funding & 68,143 & 13.19 & 6. Personnel Expenses & 4,863 & 0.94 \\
\hline Deposits & 192,413 & 37.24 & $\begin{array}{l}\text { 7. Other Administrative } \\
\text { Expenses }\end{array}$ & 5,608 & 1.09 \\
\hline $\begin{array}{l}\text { Wholesale Funding \& } \\
\text { Trading Liabilities }\end{array}$ & 186,739 & 36.15 & $\begin{array}{l}\text { D. Total Operating Expenses } \\
(6+7)\end{array}$ & 10,472 & 2.03 \\
\hline Other Liabilities & 30,357 & 5.88 & E. Operating Profit (C - D) & 2,906 & 0.56 \\
\hline Total Liabilities & 477,651 & 92.46 & $\begin{array}{l}\text { 8. Non-Operating Income } \\
\text { and Expenses }\end{array}$ & 299 & 0.06 \\
\hline Total Equity & 38,963 & 7.54 & F. Pre-Tax Profit $(E+/-8)$ & 3,206 & 0.62 \\
\hline \multirow[t]{3}{*}{ Total Liabilities and Equity } & 516,614 & 100 & 9. Tax Expense & 808 & 0.16 \\
\hline & & & $\begin{array}{l}\text { 10. Profit/Loss from } \\
\text { Discontinued Operations }\end{array}$ & 329 & 0.06 \\
\hline & & & G. Net Income $(F-9+/-10)$ & 2,727 & 0.53 \\
\hline Market Capitalization & 29,509 & 5.71 & & & \\
\hline$R W A s$ & 241,690 & 46.78 & & & \\
\hline TIER 1 Capital & 18,766 & 3.63 & & & \\
\hline TIER 1 Ratio (\%) & $7.7 \%$ & & & & \\
\hline Total Capital & 28,195 & 5.46 & & & \\
\hline Total Capital Ratio (\%) & $11.6 \%$ & & & & \\
\hline
\end{tabular}

\section{THE ACCOUNTING MODEL}

As already observed, the main objective of this paper is to explore the effect of an increase in minimum capital requirements on bank loan rates. As in King (2010), we define the capital ratio $(C R)$ as the ratio of the book value of equity to risk-weighted assets $(B V / R W A s)$. The $C R$ is here assumed as a proxy for the TIER 1 capital ratio. Also we consider two steady-states: the current steady-state, before the implementation of the proposed regulatory reform, and the long-term steady state, in which banks are supposed to have completed their transition to Basel III. We will use subscript " $t$ " to denote accounting values referring to the actual steady-state and subscript " $t+l$ " to indicate values in the long-term steady state.

Under the Basel III rules, financial institutions will be required to increase their equity capital relative to $R W A s$, according to the following expression:

$$
B V_{t+1}=B V_{t}+\Delta C R \cdot R W A s
$$

where $B V$ is the book value of equity, $\triangle C R$ is the rise in the capital ratio, and $R W A s$ are the risk-weighted assets of the bank. From equation (1), we can express the shift in the book value of equity $\left(\triangle B V=B V_{t+1}-B V_{t}\right)$ as follows:

$$
\Delta B V=\Delta C R \cdot R W A s
$$

Equation (2) states that, all else being equal, the higher the increase in the $C R$ and/or in the $R W A s$, the higher the increment in the book value of bank equity required to fulfill the new capital standards. We also assume that the increase in common equity is associated with a corresponding decrease in debt funding, so that the bank's total assets remain unchanged: 


$$
\Delta D=-\Delta B V=-\Delta C R \cdot R W A s
$$

where $\Delta D$ is the change in the book value of bank debt $\left(D_{t+1}-D_{t}\right)$. This change in capital structure should lead to an increase in bank earnings, given that as a bank reduces debt funding its interest expenses decrease. The effect of the lower debt level on interest expenses is given by:

$$
\Delta I \exp =\Delta D \cdot r_{d}=-\Delta B V \cdot r_{d}=-\Delta C R \cdot R W A s \cdot r_{d}
$$

where $\Delta I \exp$ is the decrease in bank interest expenses $\left(\operatorname{Iexp}_{t+1}-I \exp _{t}\right)$ and $r_{d}$ is the average cost of debt. By making use of an average cost of debt $\left(r_{d}\right)$ we are implying a proportional reduction in the various sources of funding (interbank funding, trading liabilities, deposits and wholesale funding). This is a conservative assumption, since banks would prefer to reduce the most expensive forms of liabilities (namely, the long-term debt). Equation (4) states that, for a given increase of the capital ratio, the higher the average cost of a bank's debt and/or the value of the risk-weighted assets, the higher the fall in a bank's interest expenses. The ultimate effect of a lower debt funding on bank's net income can be expressed as follows:

$$
\Delta \text { NIexp }=-\Delta I \exp \cdot(1-t)=\Delta C R \cdot R W A s \cdot r_{d} \cdot(1-t)
$$

where $\Delta$ NIexp is the increase in bank's earnings resulting from the decrease in interest expenses, while $t$ is the bank's average tax rate. By multiplying by one minus the tax rate, we are taking into account the effect arising from the partial loss of the tax shield on interest payments. Although the net income increases, the return on equity should decrease, since the relative increase in earnings (the numerator of the ratio) is usually lower than the rise in common equity (the denominator of the ratio). Indeed, by recalling equation (1), the effect of the change in leverage on bank's ROE can be quantified as follows:

$$
\begin{aligned}
\Delta R O E= & R O E_{t+1}-R O E_{t}=\frac{N I_{t+1}}{B V_{t+1}}-\frac{N I_{t}}{B V_{t}}= \\
= & \frac{N I_{t}+\Delta N I}{B V_{t}+\Delta C R \cdot R W A s}-\frac{N I_{t}}{B V_{t}}= \\
= & \frac{\Delta N I \cdot B V_{t}-N I_{t} \cdot \Delta C R \cdot R W A s}{B V_{t} \cdot\left(B V_{t}+\Delta C R \cdot R W A s\right)} \\
= & \frac{\Delta N I-R O E_{t} \cdot \Delta C R \cdot R W A s}{B V_{t}+\Delta C R \cdot R W A s}
\end{aligned}
$$

where $\Delta N I=N I_{t+1}-N I_{t}$ is the difference between a bank's net income in the new steady-state (after the reduction of leverage) and a bank's earnings in the baseline scenario (before the increase in capital requirements). To the extent that the only shift in a bank's earnings consists of interest expenses reduction (i.e. $\Delta N I=\Delta$ NIexp), looking at Equations (5) and (6) we find that the change in ROE can be represented by the following disequation:

$$
\begin{gathered}
\Delta N I \exp -R O E_{t} \cdot \Delta C R \cdot R W A s \lesseqgtr 0 \\
\Delta C R \cdot R W A s \cdot r_{d} \cdot(1-t)-R O E_{t} \cdot \Delta C R \cdot R W A s \lesseqgtr 0 \\
\Delta C R \cdot R W A s \cdot\left[r_{d} \cdot(1-t)-R O E_{t}\right] \lesseqgtr 0
\end{gathered}
$$

Hence, as long as the average post-tax cost of debt cost $\left[r_{d} \cdot(1-t)\right]$ is lower than the bank's return on equity in the current steady-state $\left(R O E_{t}\right)$, higher capital requirements have a negative impact on financial institutions' economic performance $(\triangle R O E<0)$. The fall in ROE will, in turn, likely lead to a decrease in bank market value, since investors' expectations with regard to future dividends per share are negatively affected by the lower ROE level. 
In view of the assumptions made above, if financial intermediaries aim to avoid a decrease of market capitalization, they should find a way of generating extra-profits from existing investments. Given the reduction in bank's interest expenses resulting from the lower debt funding, the extra-profits that our representative bank needs to generate can be easily obtained by combining equations (5) and (6), contextually imposing the shift in bank's ROE to be zero $(\triangle R O E=0)$ :

$$
\begin{gathered}
\Delta N I=R O E_{t} \cdot \Delta C R \cdot R W A s \\
E X p+\Delta N I \exp =R O E_{t} \cdot \Delta C R \cdot R W A s \\
E X p=\Delta C R \cdot R W A s \cdot\left[R O E_{t}-r_{d} \cdot(1-t)\right]
\end{gathered}
$$

where the change in bank profits $(\Delta N I)$ is now the sum of the increase in earnings associated with lower interest expenses $(\triangle$ NIexp) plus the target extra-profits our bank needs to generate $(E X p)$. As told, in the base case scenario we assume that banking institutions will compensate any additional costs resulting from Basel III only and exclusively by raising interest rates on loans, with no change in other sources of income and no reduction in operating expenses. By indicating with $\alpha$ the increment in the average interest rate charged on loans, the impact of a rise in lending rates on bank net income may be expressed as follows:

$$
\Delta N \operatorname{Iinc}=\alpha L_{t}(1-\mathrm{t})
$$

where $\Delta$ NIinc is the change resulting from the increase in lending rates $(\alpha), L_{t}$ is the total amount of loans in the current steady-state ("net loans" in table 2) and $t$ is the average tax rate.

The effect of the higher capital requirements on bank loan rates is then obtained by calibrating the rise in the average interest rate on loans which is required to generate the target extra-profits $(\Delta N I i n c=E X p)$. By combining equations (8) and (9), we get the following expression:

$$
\alpha L_{t}(1-\mathrm{t})=\Delta C R \cdot R W A s \cdot\left[R O E_{t}-r_{d} \cdot(1-t)\right]
$$

By solving equation (10) for $\alpha$, we find the increase in loan interest rates which is required to keep the bank's return on equity unchanged:

$$
\alpha=\Delta C R \cdot \frac{R W A s}{L_{t}} \cdot\left(\frac{R O E_{t}}{1-t}-r_{d}\right)
$$

Looking at equation (11) we find that, as long as debt is replaced by new shareholders' equity and the cost of debt remains unchanged, the required increase in loan rates $(\alpha)$ in the long-term steady-state is positively correlated with the increase in the capital ratio $(\triangle C R)$, the ratio of risk-weighted assets to loan portfolio $\left(R W A s / L_{t}\right)$, the return on equity before the new equity funding $\left(\mathrm{ROE}_{\mathrm{t}}\right)$ and the average tax rate $(t)$, while correlating negatively with the bank's average cost of debt $\left(r_{d}\right)$. That is to say that, for a given increment in the capital ratio, banks with higher ROE and/or with a small volume of loans relative to RWAs need a larger increase in interest rates on loans to offset the effects deriving from a lower degree of leverage. At the same time, financial institutions with a higher average cost of debt funding require a smaller change in lending rates, since they have a greater economical benefit in reducing the amount of debt relative to equity.

So far we have assumed that banks react to leverage effects associated with the new capital standards only by increasing loan interest rates to end-customers. To the extent that banks act exclusively on interest margin, the required percentage increase $(\beta)$ in interest income $\left(\right.$ Iinc $\left._{t}\right)$ can be expressed as follows:

$$
\begin{array}{r}
\beta \cdot \operatorname{Iinc}_{t} \cdot(1-t)=E X p \\
\beta=\frac{E X p}{\operatorname{Iinc}_{t} \cdot(1-t)}
\end{array}
$$


However, financial institutions have a number of alternative options to elevate earnings, such as increasing non-interest income and/or reducing personnel expenses or other administrative expenses. The following equations show the percentage change in fees and commissions, personnel expenses and other administrative expenses, required in order to gain the target extra-profits $(E X p)$ :

$$
\begin{gathered}
\gamma=\frac{E X p}{F \& C_{t} \cdot(1-t)} \\
\delta=-\frac{E X p}{P \exp p_{t} \cdot(1-t)} \\
\varepsilon=-\frac{E X p}{O \operatorname{Aexp}_{t} \cdot(1-t)}
\end{gathered}
$$

where $\gamma$ is the increase in fees and commissions $\left(F \& C_{t}\right), \delta$ is the decrease in personnel expenses $\left(P \exp p_{t}\right.$, and $\varepsilon$ is the reduction in other administrative expenses $\left(O A \exp _{t}\right)$, which are needed to achieve the target change in the bank's earnings, while maintaining interest rates on loans unchanged.

\section{RESULTS AND DISCUSSION}

Using the stylized financial statement presented in paragraph 3, we are now able to quantify the effect of increased minimum capital requirements by implementing the accounting relationships developed in the previous paragraph.

For our representative Italian bank, the ratio of risk-weighted assets to loan portfolio $\left(R W A s / L_{t}\right)$ is $80.526 \%$ (i.e. $241,690 / 300,138)$. In the baseline scenario, the return on equity $\left(R O E_{t}\right)$ is $6.999 \%$ (i.e. $2,727 /$ 38,963 ), while the average tax rate $(t)$ is $25.202 \%$ (obtained by relating tax expense to the pre-tax profit, that is 808 / 3,206 ). Finally, the average cost of bank debt $\left(r_{d}\right)$ is $2.22 \%$ (estimated as the ratio of interest expenses to total liabilities, i.e. 10,604 / 477,651). By applying those values to equation (11) we obtain the following result:

$$
\alpha=\Delta C R \cdot 0.80526 \cdot\left(\frac{0.06999}{1-0.25202}-0.0222\right)=\Delta C R \cdot 0.0575
$$

Equation (16) says that the expected increase in lending rates is $5.75 \%$ of the increment of capital ratio $(\triangle C R)$. That is to say that, for each percentage point increment in the capital ratio, our representative bank is required to elevate the average interest rate on loans by 0.0575 percentage points (i.e. $1 \% \cdot 5.75 \%$ ) in order to keep its ROE unchanged.

Table 3 synthesizes the effects of higher capital requirements on bank lending rates, by assuming a progressive rise of 1 p.p. (percentage point) in the capital ratio. Our evindence strongly suggests that higher capital requirements are likely to have a small impact on landing rates. Even a relatively-large growth in $C R$ is expected to have a modest long-term effect on interest rates faced by borrowers. For example, a six-percentage-point increment in the required regulatory capital could be offset by increasing the credit price by only 34.48 basis points (i.e. $0.3448 \%)$.

Table 3: Impact of higher capital requirements on lending rates

\begin{tabular}{cc}
\hline Increase in Capital Ratio (\%) & Increase in lending rates $(\%)$ \\
\hline 0 & 0 \\
+1 & +0.0575 \\
+2 & +0.1149 \\
+3 & +0.1724 \\
+4 & +0.2299 \\
+5 & +0.2874 \\
+6 & +0.3448 \\
\hline
\end{tabular}


Table 4 shows how our representative bank could generate the same extra-profits required to keep its ROE unchanged, either by raising non-interest income (fees and commissions), or by reducing its operating expenses (personnel expenses or other administrative expenses), while maintaining the current interest rates on loans.

Values in column two are obtained from equation (6) by assuming the bank's return on equity to be unchanged $\left(\triangle N I=R O E_{t} \cdot \Delta C R \cdot R W A s\right)$. On the basis of accounting data from our representative bank's financial statement, Italian listed banks need a shift in net income of 169.158 Million Euros for each p.p. increase in the $C R$ (i.e. $6.999 \% \cdot 1 \% \cdot 241,690$ ), which corresponds to a 6.2 p.p. rise in net income for every 1 p.p. increment in the $C R$. By applying equation (8) we also find that, when considering the reduction of bank interest expenses ( $\Delta$ NIexp), the representative bank needs to generate 129.03 Million Euros of extra-profits for each p.p. increase in the CR [i.e. $1 \%$ - 241,690 - [6.999\% - 2.22\% - (1-25.202\%)]]. From equation (12) we estimate that those extra-profits could be gained by increasing the bank's interest income by $0.91 \%$ [i.e. $129.03 /$ [18,908 $\cdot(1-25.202 \%)]$ for each p.p. increase in the $C R$.

Table 4: Role of non-interest income and expenses under higher capital requirements

\begin{tabular}{cccccc}
\hline $\begin{array}{c}\text { Increase in } \\
\text { Capital Ratio } \\
(\%)\end{array}$ & $\begin{array}{c}\text { Required increase } \\
\text { in earnings }\end{array}$ & Interest Income & Fees and commissions & $\begin{array}{c}\text { Personnel } \\
\text { expenses }\end{array}$ & $\begin{array}{c}\text { Other administrative } \\
\text { expenses }\end{array}$ \\
\cline { 3 - 6 } & 0 & 0 & 0 & 0 & 0 \\
+1 & $6.20 \%$ & $0.91 \%$ & $3.74 \%$ & $-3.55 \%$ & $-3.08 \%$ \\
+2 & $12.41 \%$ & $1.82 \%$ & $7.47 \%$ & $-7.09 \%$ & $-6.15 \%$ \\
+3 & $18.61 \%$ & $2.74 \%$ & $11.21 \%$ & $-10.64 \%$ & $-9.23 \%$ \\
+4 & $24.81 \%$ & $3.65 \%$ & $14.94 \%$ & $-14.19 \%$ & $-12.30 \%$ \\
+5 & $31.02 \%$ & $4.56 \%$ & $18.68 \%$ & $-17.74 \%$ & $-15.38 \%$ \\
+6 & $37.22 \%$ & $5.47 \%$ & $22.42 \%$ & $-21.28 \%$ & $-18.46 \%$ \\
\hline
\end{tabular}

As an alternative to raising lending rates, according to equation (13) the required increment in net income can be reached by raising revenues from service activities (fees and commissions) by 3.74 percentage points for each p.p. increase in the $C R$ [i.e. 129.03 / [4,617 - (1-25.202\%)]], that is more than four times as much as the interrelated shift required for interest income. Indeed, although most Italian banks are diversifying into fee-based activities, they are still focused on traditional forms of intermediation (i.e. lending business) and, as a consequence, the income arising from sources other than interest accounts for a small part of total revenues. Looking at table 2, fees and commissions constitute less than $25 \%$ of interest income (i.e. 4,617 / 18,908). Hence, if banks want to use non-interest income to enhance their profitability, they need to make proportionally higher changes in their income statements' structure.

On the other hand, financial institutions could also work on their cost structure to improve efficiency standards. Although the increased competition has forced many Italian banks to develop efficiency-related strategies, in many cases they still operate under high-cost conditions, which are mainly related to labour costs and/or other administrative expenses. Based on our representative bank's income statement, personnel account for $58.8 \%$ of net interest income (i.e. 4,863/8,304) and $36.3 \%$ of total revenues $(4,863 / 13,378$ ), while other administrative costs constitute $67.5 \%$ of net interest income (i.e. 5,608/8,304) and $41.9 \%$ of total revenues (i.e. $5,608 / 13,378)$. Those values suggest that effective actions towards the containment of operating costs may have a significant impact on a bank's annual earnings. Indeed, by applying equations (14) and (15) we find that the fall in ROE associated with a 1 p.p. increase in the $C R$ can be recovered, alternatively, by reducing personnel expenses by 3.55 p.p. [i.e. $129.03 /$ [4,863 - (1-25.202\%)]] or by decreasing other administrative costs by 3.08 p.p. [i.e. 129.03 / $[5,608 \cdot(1-25.202 \%)]]$.

Of course, Italian banks could also adjust to higher capital requirements through a combined strategy involving both income and cost drivers. From this point of view, the new regulatory framework might encourage financial institutions to explore new operative solutions in order to improve efficiency and profitability standards. 


\section{CONCLUSIONS AND FUTURE RESEARCH}

The accounting-based model developed in this study reveals that the expected increase in lending rates associated with increased capital standards relates positively to the risk-weighted assets to loan portfolio ratio, with the bank's ROE and with the average tax rate, while it is negatively correlated with the bank's average cost of debt.

Empirical estimates based on aggregated accounting magnitudes of Italian listed banks document that substantially higher capital requirements are likely to have a relatively small impact on interest rates charged on loans. In our baseline scenario, each percentage point increase in the capital ratio is expected to increase loan rates by only 5.75 basis points (i.e. $0.0575 \%$ ). If we assume positive changes in non-interest income drivers (fees and commissions) and/or in operative expenses, the impact of the new regulatory framework on lending rates is even lower. Therefore, based on our evidence, Italian banking system should be able to adjust to the higher capital requirements imposed by Basel III through a combination of operative and commercial actions, with no significant impact on credit prices.

Our results are in line with previous literature findings. Nevertheless, as observed, we believe the present study is original in two aspects. First, it deals specifically with the Italian banking sector, while most existing literature refers to contexts such as the U.S.A., the U.K. or OECD zone. Second, it is based on a pragmatic and flexible approach resting on general accounting relations, which can be easily used to calibrate the effects arising from changes in a bank's balance sheet structure and/or in income statement configuration.

Of course, our approach has its limitations. First of all, our estimates could be distorted by the internal heterogeneity of the banks' sample in terms of size, governance profiles and operating models. Also, we completely ignored the classical Modigliani and Miller (M-M) financial theorem on corporate capital structure. Under the M-M framework a reduction of financial leverage leads to a decrease in the required rate of return on both equity and debt, because of the lower risk premium that investors would demand. This happens in such a way that the overall impact of a decrease in the debt to equity ratio on the company's market value is zero (Modigliani and Miller, 1958). For the purposes of this research, we have assumed that neither the cost of equity capital, nor the cost of debt funding, is affected by the change in capital structure ${ }^{3}$. Finally, while the Basel Committee proposals imply changes both in capital and liquidity requirements, this research focuses exclusively on the effects of the higher capital standards. However, the new liquidity requirements could also have some cost implications, such as lower interest income (since banks are required to hold more liquid and less risky assets) and higher interest expenses (associated with debt maturity extension).

Future research could explore the effect of interactions between the new capital and liquidity standards, as well as the extent to which the M-M propositions might change our conclusions. However, the required adjustments to higher capital standards appears to be so much smaller that we believe further corrections would not imply a large degree of change.

\section{AUTHOR INFORMATION}

Dr. Pasquale di Biase is assistant professor and graduate teacher of Economics of Financial Intermediaries at the University of Foggia (Italy). He earned Ph.D. degree in Banking and Finance from the University of Calabria (Italy). He published and is involved in a number of researches on capital markets and banking sector regulation. E-mail: p.dibiase@unifg.it

\footnotetext{
${ }^{3}$ Although this is a conservative hypothesis, which dilates our estimates regarding the effects of the new capital requirements on bank loans rates, there are a number of reasons for assuming that the classic M-M model does not entirely hold true for banks. In addition to tax distortions (i.e. the tax advantage arising from debt financing), a significant departure from the $\mathrm{M}-\mathrm{M}$ model stems, in the case of banks, from the explicit public guarantee on deposits (i.e. the deposit insurance system) and the implicit government guarantees on banks' debt (since investors assume that the government will not let banks default on their debt) (Elliott, 2009; King, 2010).
} 


\section{REFERENCES}

1. Admati, A.R., DeMarzo, P.M., Hellwig, M.F., \& Pfleiderer, P. (2011). Fallacies, Irrelevant Facts, and Myths in the Discussion of Capital Regulation: Why Bank Equity is Not Expensive. Stanford GSB Research Paper, 2065. Retrieved from: http://ssrn.com/abstract=1669704

2. Basel Committee on Banking Supervision (2009). Strengthening the resilience of the banking sector Consultative Document. Bank for International Settlements. Retrieved from: http://www.bis.org/publ/bcbs164.pdf

3. Basel Committee on Banking Supervision (2010a). Basel III: International framework for liquidity risk measurement, standards and monitoring. Bank for International Settlements. Retrieved from: http://www.bis.org/publ/bcbs188.pdf

4. Basel Committee on Banking Supervision (2010b). An assessment of the long-term economic impact of stronger capital and liquidity requirements. Bank for International Settlements. Retrieved from: http://www.bis.org/publ/bcbs173.pdf

5. Berger, A.N., Herring, R., \& Szego, G.P. (1995). The Role of Capital in Financial Institutions. Journal of Banking and Finance, 19(3-4), 393-430.

6. Berger, A.N., \& Bouwman, C.H.S. (2011). How Does Capital Affect Bank Performance During Financial Crises?. Wharton Financial Institutions Center Working Paper Series, 11/22. Retrieved from: http://fic. wharton.upenn.edu/fic/papers/11/11-36.pdf

7. Cosimano, T.F., \& Hakura, D.S. (2011). Bank Behavior in Response to Basel III: A Cross-Country Analysis. IMF Working Paper, 11/119. Retrieved from: http://www.imf.org/external/pubs/ft/wp/2011/wp11119.pdf

8. Elliott, D.J. (2009). Quantifying the Effects on Lending of Increased Capital Requirements. Pew Financial Reform Project Briefing Paper, 7. Retrieved from: http://www.pewtrusts.org/uploadedFiles/wwwpewtrustsorg/Reports/Economic_Mobility/Elliott-Capitalfinal.pdf

9. Kashyap, A.K., Stein, J., \& Hanson, S. (2010). An Analysis of the Impact of 'Substantially Heightened' Capital Requirements on Large Financial Institutions. Harvard University Working Paper. Retrieved from: http://www.people.hbs.edu/shanson/Clearinghouse-paper-final_20100521.pdf"

10. King, M.R. (2010). Mapping capital and liquidity requirements to bank lending spreads. BIS Working Paper, 324. Retrieved from: http://www.bis.org/publ/work324.pdf

11. Maccario, A., Sironi, A., \& Zazzara, C. (2002). Is Banks' Cost of Equity Capital Different Across Countries? Evidence from the G10 Countries Major Banks. SDA Bocconi Research Division Working Paper, 02/77. DOI: 10.2139/ssrn.335721.

12. Macroeconomic Assessment Group (Financial Stability Board - Basel Committee on Banking Supervision). (2010). Assessing the Macroeconomic Impact of the Transition to Stronger Capital and Liquidity Requirements - Interim Report. Bank for International Settlements. Retrieved from: http://www.bis.org/publ/othp10.pdf

13. Modigliani, F., \& Miller, M. (1958). The cost of capital, corporation finance and the theory of investment. The American Economic Review, 48(3), 261-97.

14. Préfontaine, J., Desrochers, J., \& Godbout, L. (2010). Analysis And Comments On The Consultative Document: International Framework For Liquidity Risk Measurement, Standards And Monitoring. International Business \& Economics Research Journal, 9(11), 107-114. Retrieved from: http://journals.cluteonline.com/index.php/IBER/article/view/36

15. Slovik, P., \& Cournede, B. (2011), Macroeconomic Impact of Basel III. OECD Economics Department Working Papers, 844. DOI: 10.1787/5kghwnhkkjs8-en 


\section{NOTES}

